\title{
EVALUASI ZONASI TAMAN NASIONAL GUNUNG MERAPI
}

\begin{tabular}{|c|}
\hline Dian Wijayati' ${ }^{1}$ R. Rijanta \\
\hline${ }^{2}$ \\
${ }^{1}$ Mahasiswa Magister Perencanaan Kota dan Daerah, Universitas Gadjah Mada, \\
${ }^{2}$ Dosen Fakultas Geografi, Universitas Gadjah Mada \\
${ }^{1}$ dianwijayati@ gmail.com, ${ }^{2}$ rijanta@ ugm.ac.id
\end{tabular}

Diterima: Maret 2019; Direvisi: April 2019; Disetujui: Mei 2019

\begin{abstract}
Mount Merapi National Park (MMNP) is located in the region of Mount Merapi. Since the beginning of its appointment, the existence of MMNP caused cotradiction and conflict between people around Merapi and other stakeholders. Its existence is considered as a threat to limit assets, access, and their activities in the utilization of natural resources to meet their needs of life. To protect natural sustainability of Mount Merapi and refers to the regulation of national park management, MMNP is managed using zoning system. The development of MMNP zoning has considered without prejudice or harm the welfare of society, both in the aspects of conservation, economic and socio-cultural. In fact there are still wide range of violations committed by the society and other stakeholders, which indicate that the zoning has not been complied with. This research aims to evaluate the effectiveness of national park management using zoning system. The method used is deductive approach with data sources obtained from primary data in the form of observations and in-depth interviews, and secondary data in the form of documents from various sources. The results of this study indicate that zoning regulations effectively regulate the activities that carried out in each zone. However, MMNP still has "homework" to resolve grass harvesting and encroachment within MMNP.
\end{abstract}

Keywords: evaluation, effectiveness, national parks, zoning.

Abstraksi. Taman Nasional Gunung Merapi (TNGM) terletak di kawasan Gunung Merapi. Sejak penunjukkannya, keberadaan TNGM menimbulkan pertentangan dan konflik antara masyarakat Merapi maupun stakeholder lainnya. Keberadaan TNGM dianggap sebagai ancaman yang membatasi aset, akses, dan aktivitas mereka dalam pemanfaatan sumber daya alam untuk pemenuhan kebutuhan. Dalam upaya melindungi kelestarian alam kawasan Gunung Merapi dan mengacu pada peraturan pengelolaan taman nasional, maka TNGM dikelola menggunakan sistem zonasi. Pengembangan zonasi TNGM telah mempertimbangkan tanpa mengesampingkan ataupun merugikan kesejahteraan masyarakat, baik dalam aspek konservasi, ekonomi, dan sosial budaya. Namun kenyataannya masih terdapat berbagai pelanggaran dilakukan masyarakat dan stakeholder lainnya yang menunjukkan belum ditepatinya zonasi yang telah ditetapkan. Penelitian ini bertujuan mengevaluasi efektivitas pengelolaan TNGM menggunakan sistem zonasi. Metodologi yang digunakan adalah pendekatan deduktif dengan sumber data di dapat dari data primer berupa observasi dan wawancara mendalam, serta data sekunder berupa dokumen dari berbagai sumber. Hasil penelitian menunjukkan bahwa peraturan zonasi efektif mengatur aktivitas yang ada pada masing-masing zona. Namun demikian, BTNGM masih mempunyai "pekerjaan rumah" untuk mengatasi masalah perumputan dan perambahan liar di dalam kawasan TNGM.

Kata kunci: evaluasi, efektivitas, taman masional, zonasi. 


\section{PENDAHULUAN}

Gunung Merapi (yang selanjutnya disebut Merapi) merupakan gunung api aktif yang terletak di perbatasan Daerah Istimewa Yogyakarta (DIY) dan 3 kabupaten lain di Provinsi Jawa Tengah (Jateng), yaitu Kabupaten Magelang, Klaten, dan Boyolali. Dalam sejarahnya, Merapi mengalami berbagai peristiwa letusan atau erupsi. Salah satu letusan maha dahsyat Merapi yang meluluh lantakkan kawasan di sekitarnya terjadi pada tahun 2010. Ribuan jiwa menjadi korban, banyak mahluk hidup kehilangan tempat tinggal, dan mengakibatkan terpuruknya perekonomian di sekitar Merapi.

Selain bencana yang ditimbulkan, Merapi membawa keberkahan bagi kehidupan mahluk hidup di sekitarnya. Kawasan hutan Merapi termasuk hutan hujan tropis yang di dalamnya terdapat keanekaragaman hayati, sumber plasma nutfah, mempunyai fungsi sosial ekonomi, religi, dan budaya. Selain itu, kawasan hutan Merapi berfungsi sebagai daerah tangkapan air yang bermanfaat bagi wilayah sekitarnya, terutama merupakan sumber air bagi daerah aliran sungai Progo di bagian barat, sungai Opak di bagian selatan, dan sungai Bengawan Solo di sebelah Timur. Sejak tahun 2004 kawasan hutan Merapi ditunjuk sebagai Taman Nasional Gunung Merapi (TNGM) sesuai dengan Surat Keputusan Menteri Kehutanan No.134/Menhut-II/2004. Landasan lahirnya TNGM adalah sebagai perlindungan terhadap habitat flora fauna di dalamnya, perlindungan sumber air bagi masyarakat sekitar, perlindungan serta pengembangan wisata alam yang luar biasa, dan budaya masyarakat yang menarik. TNGM dikelola oleh sebuah Balai yaitu Balai Taman Nasional Gunung Merapi (BTNGM). BTNGM dalam menjalankan tugasnya berpegang pada visi menjadi taman nasional yang mantap dalam mengelola ekosistem volcano yang dinamis dan berbasis partisipasi para pihak (BTNGM, 2015). Sebagai upaya mewujudkan visi tersebut, BTNGM merumuskan misi yaitu meningkatkan kapasitas kelembagaan berbasis tata kelola hutan yang baik dan pengelolaan tingkat tapak, merestorasi ekosistem vulkano yang dinamis dan mitigasi bencana vulkanik, serta meningkatkan partisipasi para pihak dalam pengelolaannya (BTNGM, 2015).

TNGM memiliki wilayah seluas 6.607,52 Ha. TNGM dalam pengelolaannya dibagi menjadi 2 Seksi Pengelolaan Taman Nasional (SPTN), yaitu SPTN Wilayah I dan SPTN Wilayah II. SPTN Wilayah I terdiri dari Resort Cangkringan, Pakem Turi, Srumbung, dan Dukun. SPTN Wilayah II terdiri dari Resort Selo, Musuk Cepogo, dan Kemalang. Kawasan TNGM berbatasan langsung dengan 30 desa yang berfungsi sebagai desa penyangga. Sebanyak 23 desa terdapat di Provinsi Jateng dan 7 desa di DIY. Pengelolaan TNGM tidak dapat terlepas dari keberadaan desa-desa penyangga di sekitarnya. Hal ini disebabkan keberadaan desa-desa penyangga tersebut sudah ada terlebih dulu sebelum penetapan TNGM. Ketergantungan masyarakat desa penyangga terhadap sumber daya alam Merapi telah berlangsung secara turun temurun. Mulai dari pemanfaatan sumber air, rumput untuk pakan ternak, kebutuhan kayu bakar dan kayu pertukangan, perburuan satwa, perambahan lahan, penambangan pasir, serta kebutuhan ritual religi dan budaya. Penetapan hutan di kawasan Merapi sebagai TNGM tidak serta merta menghentikan aktivitas masyarakat di dalamnya. Pada awal penunjukkan TNGM terjadi resistensi dari masyarakat sekitar kawasan Merapi. 
Keberadaan TNGM dianggap sebagai ancaman yang membatasi aset, akses, dan aktivitas mereka dalam pemanfaatan sumber daya alam yang berada di dalamnya untuk pemenuhan kebutuhan. Perlawanan dari masyarakat ini terjadi karena ketidak mengertian mereka akan tujuan ditunjuknya kawasan Merapi sebagai TNGM. Di samping itu banyak beredar informasi tidak benar tentang konsekuensi terbatasinya aset, akses, dan aktivitas yang harus diterima masyarakat atas penunjukkan TNGM. Beberapa informasi tersebut, yaitu akan dibangun pagar mengelilingi kawasan TNGM sehingga masyarakat tidak dapat mengakses sumber daya alam yang ada di dalamnya dan tanah milik masyarakat akan diambil alih menjadi bagian dari kawasan TNGM.

Berdasarkan Undang-Undang Nomor 5 Tahun 1990 tentang Konservasi Sumber Daya Alam Hayati dan Ekosistemnya, pengelolaan taman nasional dilakukan menggunakan sistem zonasi. Sebagai mana disebutkan dalam Pasal 1 Undang-Undang Nomor 5 Tahun 1990 definisi dari "taman nasional adalah kawasan pelestarian alam yang mempunyai ekosistem asli, dikelola dengan sistem zonasi yang dimanfaatkan untuk tujuan penelitian, ilmu pengetahuan, pendidikan, menunjang budidaya, pariwisata, dan rekreasi." Menurut Peraturan Menteri Kehutanan (Permenhut) Nomor 56 Tahun 2006 tentang Pedoman Zonasi Taman Nasional, "zonasi taman nasional adalah suatu proses pengaturan ruang dalam taman nasional menjadi zonazona, yang mencakup kegiatan tahap persiapan, pengumpulan dan analisis data, penyusunan draft rancangan zonasi, konsultasi publik, perancangan, tata batas, dan penetapan, dengan mempertimbangkan kajian-kajian dari aspek-aspek ekologis, sosial, ekonomi, dan budaya masyarakat."
Peraturan Menteri Lingkungan Hidup dan Kehutanan (Permenlhk) Nomor P.76/Menlhk-Setjen/2015 tentang Kriteria Zona Pengelolaan Taman Nasional, Blok Pengelolaan Cagar Alam, Suaka Margasatwa, Taman Hutan Raya, dan Taman Wisata Alam mengamanatkan zona dalam kawasan taman nasional terdiri dari zona inti, zona rimba, zona pemanfaatan, dan zona lainnya sesuai dengan keperluan (zona perlindungan bahari; zona tradisional; zona rehabilitasi; zona religi, budaya, dan sejarah; serta zona khusus).

Berangkat dari realita ketergantungan masyarakat akan sumber daya alam di kawasan hutan Merapi, untuk melindungi kelestarian alam kawasan Merapi dan mengacu pada peraturan pengelolaan taman nasional, maka TNGM dikelola menggunakan sistem zonasi. Berdasarkan hasil review zonasi TNGM tahun 2015, zona TNGM saat ini terbagi menjadi 7 zona, yaitu zona inti; rimba; pemanfaatan; rehabilitasi; tradisional; religi, budaya, dan sejarah; serta zona khusus mitigasi dan rekonstruksi. Masing-masing zona mempunyai peruntukan ruang yang berbeda. Peta zonasi TNGM tahun 2016 dapat dilihat pada Gambar 1.

Pengelolaan TNGM menggunakan sistem zonasi telah dilaksanakan sejak awal penunjukan kawasan Merapi sebagai TNGM. BTNGM dalam menentukan zonasi di TNGM dengan melalui berbagai macam kajian keilmuan dan konsultasi publik melibatkan berbagai pihak yang berkepentingan di dalam kawasan TNGM, yaitu Pemerintah Provinsi Jateng, Pemerintah DIY, Pemerintah Kabupaten Magelang, Pemerintah Kabupaten Boyolali, Pemerintah Kabupaten Klaten, dan Pemerintah Kabupaten Sleman, serta masyarakat sekitar kawasan TNGM. Pengembangan zonasi TNGM tersebut 
telah mempertimbangkan tanpa kesejahteraan masyarakat, baik dalam aspek konservasi, ekonomi, dan sosial budaya. Namun kenyataannya masih terdapat berbagai pelanggaran yang dilakukan oleh masyarakat dan stakeholder lainnya yang menunjukkan belum ditepatinya zonasi yang telah ditetapkan oleh BTNGM. Sebagai contoh adalah masih terdapatnya aktivitas penambangan pasir di dalam kawasan TNGM. Melimpahnya material berupa pasir dan batu di kawasan Merapi tidak hanya membawa berkah untuk masyarakat sekitar Merapi, namun juga menarik masyarakat luar daerah serta pemodal besar untuk turut mendapatkan penghasilan dengan melakukan penambangan pasir. Di sisi lain, ada sebagian masyarakat Merapi yang menentang aktivitas penambangan di kawasan Merapi, terutama jika dikaitkan dengan terancamnya keberlangsungan fungsi ekologi Merapi. Penambangan pasir memberikan dampak kerusakan wilayah, yang apabila dihitung secara ekonomi, biaya pemulihannya lebih besar, jauh dari manfaat ekonomi yang diberikan (Kuswijayanti, dkk, 2007).
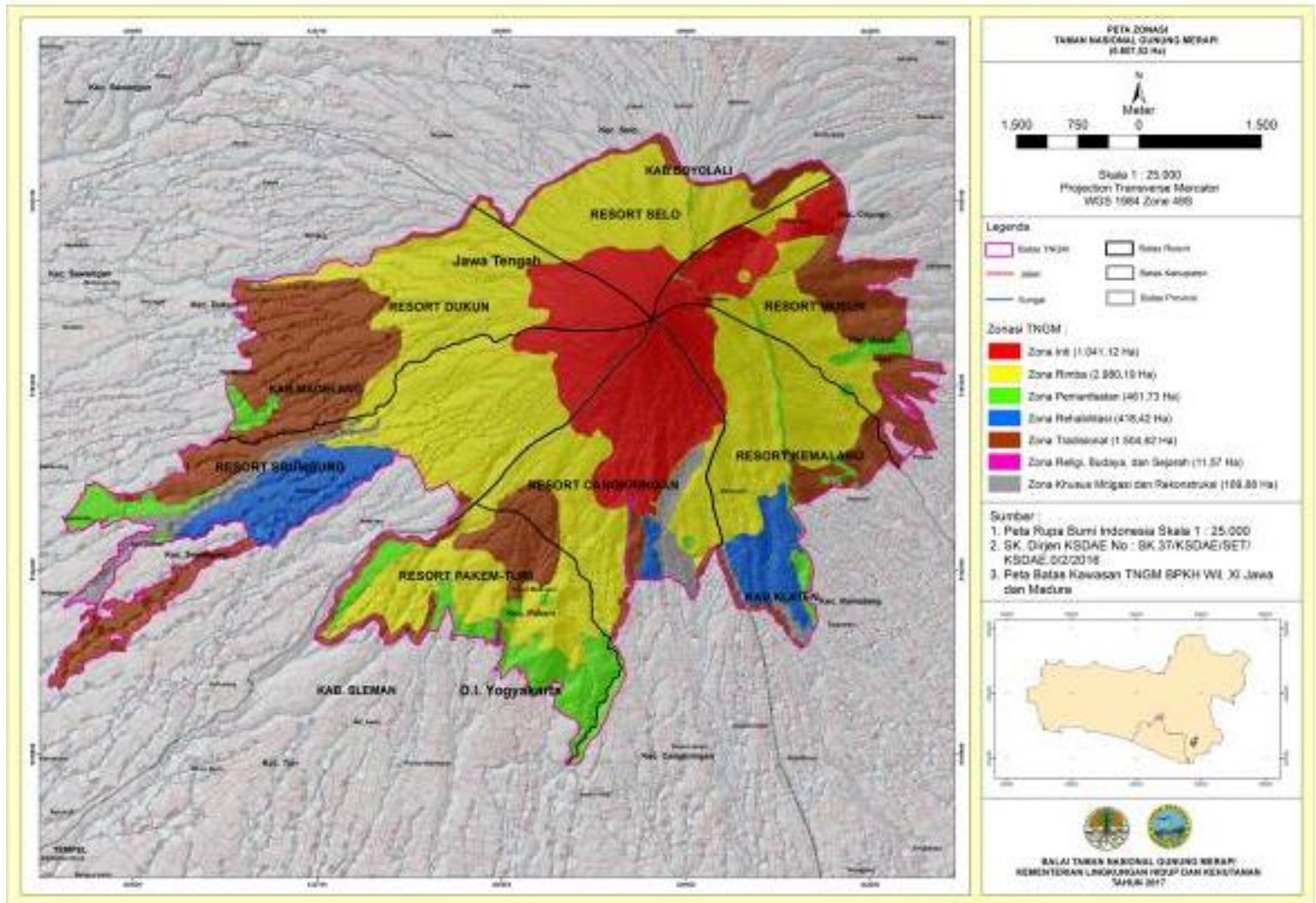

Gambar 1. Peta Zonasi Kawasan TNGM Tahun 2016

Sumber: TNGM, 2016

Melihat dinamisnya aktivitas masyarakat Merapi dan para pihak yang berkepentingan di kawasan Merapi, maka perlu dilakukan evaluasi terhadap zonasi TNGM yang telah ditetapkan, apakah terdapat ketidaksesuaian antara zonasi yang telah ditetapkan dengan kondisi saat ini yang terjadi di lapangan. Nugroho (2012) mengatakan bahwa "evaluasi akan memberikan informasi yang valid dan dapat dipercaya mengenai kinerja kebijakan yaitu seberapa jauh kebutuhan, nilai dan kesempatan yang telah dicapai 
melalui tindakan publik." Evaluasi dapat diukur melalui 5 dimensi, yaitu indikator masukan (input), proses, keluaran (output), hasil (outcome), dan dampak (impact) (Subarsono, 2005). Dalam melakukan evaluasi diperlukan kriteria-kriteria yang merupakan penentu kualitas dari evaluasi yang dilaksanakan. Komponen evaluasi jika dikaitkan dengan struktur manajemen pemerintahan dapat dilakukan untuk mengukur kinerja pembangunan melalui indikator input, output, outcome atau impact (Bappenas, 2009). Lebih lanjut kriteria evaluasi menurut Bappenas (2009) yaitu relevansi, keefektifan, hasil, dampak, dan keberlanjutan. Dunn (1994) dalam Wibawa, dkk (2009) menggambarkan kriteria-kriteria evaluasi yaitu efektivitas, efisiensi, kecukupan, perataan, responsivitas, dan ketepatan.

Penelitian ini bertujuan untuk mengetahui output dari pengelolaan TNGM menggunakan sistem zonasi. Kriteria yang digunakan dalam penelitian ini adalah efektivitas. Penilaian efektivitas digunakan untuk mengetahui tingkat keberhasilan suatu program atau kegiatan dalam pencapaian tujuan yang telah ditetapkan. Keberhasilan suatu program atau kegiatan dalam pencapaian tujuan tidak dapat dipisahkan dari kebijakan yang menjadi rujukan untuk mengatur apa yang boleh dan tidak boleh dilakukan. Evaluasi memiliki fungsi penting dalam analisis kebijakan, yaitu sebagai pemberi informasi yang valid dan dapat dipercaya mengenai kinerja kebijakan; memberi sumbangan terhadap klarifikasi dan kritik terhadap nilai-nilai yang mendasari pemilihan tujuan dan target dalam kebijakan publik; serta memberi sumbangan pada aplikasi metode-metode analisis kebijakan lainnya, termasuk dalam perumusan masalah maupun rekomendasi pemecahan masalah (Dunn, 1998 dalam Nugroho, 2009).

Hasil penelitian ini diharapkan dapat memberikan masukan dan bahan pertimbangan bagi pemerintah, khususnya BTNGM sebagai pemangku kawasan terkait implementasi peraturan zonasi di TNGM. Dalam hal ini masyarakat tidak hanya diposisikan sebagai obyek penerima manfaat dari diimplementasikannya peraturan zonasi, namun mengikutsertakan kepentingan masyarakat dalam setiap pengambilan kebijakan. Penelitian ini diharapkan dapat menambah pengetahuan mengenai implementasi peraturan zonasi dan sebagai referensi bagi penelitian ilmiah lainnya terkait degan topik penelitian ini.

\section{METODE PENELITIAN}

Pendekatan penelitian evaluasi zonasi pada TNGM menggunakan alur pemikiran deduktif. Metode deduktif dilakukan dengan pendalaman terhadap teori-teori yang relevan untuk menghasilkan kriteria dan variabel sebagai alat untuk melihat dan menguji kenyataan yang terjadi di lapangan. Alur pemikiran deduktif digunakan karena penelitian ini menggunakan acuan teori untuk menyusun indikator-indikator untuk mengevaluasi implementasi zonasi di TNGM. Lokasi pada penelitian ini adalah TNGM yang terletak di dua provinsi, yaitu Provinsi Jateng dan DIY, serta 4 kabupaten, yaitu Kabupaten Magelang, Boyolali, Klaten, dan Sleman. Penelitian dilakukan pada seluruh kawasan TNGM dengan pertimbangan bahwa zonasi diimplementasikan di seluruh kawasan TNGM.

Data yang diperlukan dalam penelitian ini meliputi data primer dan data sekunder. Data primer diperoleh melalui observasi lapangan maupun wawancara. Observasi dilakukan untuk mengumpulkan data-data 
secara langsung yang berguna sebagai pendukung terhadap penilaian kriteria evaluasi. Wawancara dilakukan dengan indepth interview pada narasumber terseleksi dengan menggunakan pedoman wawancara sebagai alat bantu. Adapun narasumber yang dipilih adalah narasumber yang dianggap paling memiliki pengetahuan dan lebih memahami situasi. Narasumber dipilih dari masyarakat dan pihak pemangku kepentingan. Data sekunder diperoleh dari buku-buku atau dokumen, data-data statistik, peta-peta tematik, dan data relevan lainnya yang digunakan untuk menjelaskan mengenai proses implementasi kebijakan zonasi pada TNGM. Data yang didapat dari hasil observasi, wawancara, dan data sekunder kemudian diolah dan dianalisa terkait dengan evaluasi zonasi pada TNGM.

\section{HASIL DAN PEMBAHASAN}

Sejak awal pembentukan BTNGM, zonasi TNGM telah mengalami beberapa kali perubahan. Review zonasi pertama dilaksanakan pada tahun 2008, menghasilkan penambahan zona mitigasi luncuran lava, penghapusan zona pemanfaatan pasir, serta revisi zona pemanfaatan wisata alam, dan tradisional. Review selanjutnya dilaksanakan pada tahun 2012 berdasarkan kondisi TNGM yang sebagian besar rusak akibat erupsi Merapi tahun 2010. Dalam kurun waktu 4 tahun dari tahun 2012, telah terjadi perubahan potensi tutupan lahan, satwa liar, dan sosial ekonomi masyarakat sehingga dilakukan perubahan zonasi berdasarkan aspek vulkanologi, ekologi, fisik, sosial ekonomi, dan budaya, serta merupakan hasil pembahasan konsultasi publik tingkat DIY, Kabupaten Sleman, dan Kabupaten Magelang. Review zonasi dilaksanakan pada tahun 2015 dan ditetapkan pada tahun
2016, serta masih berlaku sampai dengan saat ini.

Dalam rentang waktu sejak TNGM dikelola oleh BTNGM sampai dengan saat ini, perlu dievaluasi output dalam pengelolaan TNGM menggunakan sistem zonasi. Kriteria yang digunakan dalam penilaian ketercapaian output ini adalah efektivitas. Pengukuran efektivitas zonasi pada TNGM dilakukan dengan membandingkan jenis kegiatan yang diperbolehkan di dalam masing-masing zona berdasar Permenlhk Nomor P.76/Menlhk-Setjen/2015 dengan kondisi existing aktivitas yang terjadi di dalam kawasan TNGM. Pengukuran efektivitas zonasi TNGM dilakukan untuk mengetahui seberapa jauh masyarakat dan stakeholder lainnya menaati peraturan zonasi sesuai yang telah ditetapkan pada masing-masing zona. Hal ini tidak terlepas dari kenyataan bahwa TNGM terletak berbatasan langsung dengan desa-desa penyangga dimana sebagian besar masyarakat hidup tergantung dari sumber daya alam yang dimiliki oleh TNGM. Hasil pengamatan evaluasi efektivitas pada masing-masing zona di TNGM tersaji pada Tabel 1 dengan initial masing-masing zona yaitu ZI untuk inti; ZRi untuk rimba; ZP untuk pemanfaatan; $\mathrm{ZTr}$ untuk tradisional; Zre untuk rehabilitasi; ZBS untuk religi, budaya, dan sejarah; serta ZKh untuk khusus mitigasi dan rekonstruksi. Evaluasi efektivitas pada masing-masing zona di TNGM menunjukkan hasil:

\section{Zona Inti}

Zona inti TNGM diperuntukan untuk melindungi wilayah kepundan Merapi yang memiliki karakteristik geomorfologi khas dengan ekosistem vulkaniknya dan kawasan Gunung Bibi yang memiliki keanekaragaman hayati khas ekosistem Merapi. Menurut kepercayaan masyarakat 
Merapi, Gunung Bibi memiliki nilai sakral tersendiri. Menurut sejarahnya Gunung Bibi belum pernah terkena dampak langsung dari erupsi Merapi sehingga terlarang untuk aktivitas dan harus selalu dijaga supaya mereka terhindar dari bencana.

Hasil evaluasi menunjukkan peraturan zonasi efektif mengatur semua yang berhubungan dengan aktivitas dalam mencapai tujuan yang diharapkan pada Resort Cangkringan, Srumbung, Dukun, Selo, Kemalang, dan Musuk Cepogo, kecuali Resort Turi Pakem karena tidak terdapat zona inti di dalamnya.

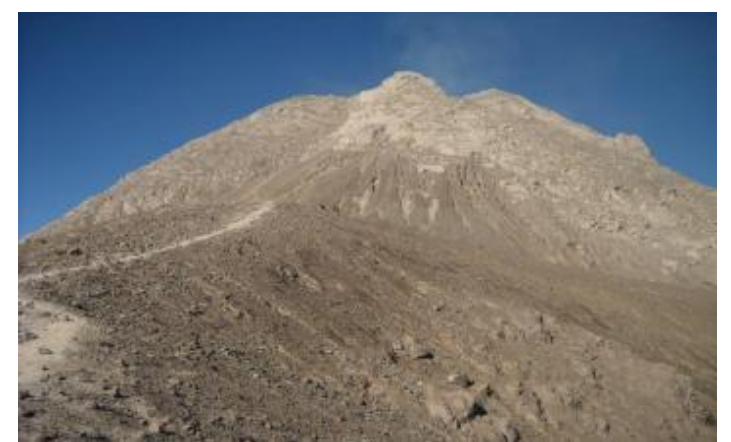

Gambar 2. Kepundan Gunung Merapi Sumber: TNGM, 2016

Tabel 1.

Ringkasan Evaluasi Efektivitas Implementasi Zonasi TNGM
Keefektifan peraturan zonasi yang diterapkan pada zona inti merupakan hasil upaya BTNGM merangkul masyarakat Merapi melalui berbagai program, kegiatan, dan pendekatan personal sehingga timbul kesadaran dari masyarakat dan stakeholder lainnya untuk ikut menjaga kawasan Merapi. Seperti yang disampaikan oleh Kepala Resort Selo bahwa dalam melakukan pengamanan, petugas dari BTNGM tidak dapat mengawasi setiap waktu karena keterbatasan jumlah petugas, maka pendekatan secara personal sangat efektif dalam menumbuhkan kesadaran masyarakat akan arti pentingnya menjaga kawasan TNGM. Tidak hanya memberikan efek jera pada pelaku pelanggaran di kawasan TNGM, namun juga merayu hati dan menumbuhkan "ewuh pekewuh" masyarakat untuk menjaga kelestarian kawasan TNGM.

\begin{tabular}{|c|c|c|c|c|c|c|c|c|c|c|c|c|c|c|}
\hline \multirow{2}{*}{ Lokasi Resort } & \multicolumn{2}{|c|}{$\mathrm{ZI}$} & \multicolumn{2}{|c|}{$\mathrm{ZRi}$} & \multicolumn{2}{|c|}{$\mathrm{ZP}$} & \multicolumn{2}{|c|}{$\mathrm{ZTr}$} & \multicolumn{2}{|c|}{ Zre } & \multicolumn{2}{|c|}{ ZBS } & \multicolumn{2}{|c|}{$\mathrm{ZKh}$} \\
\hline & + & - & + & - & + & - & + & - & + & - & + & - & + & - \\
\hline Cangkringan & 7 & 0 & 7 & 1 & 11 & 0 & 6 & 0 & 6 & 0 & 8 & 0 & 6 & 0 \\
\hline Turi Pakem & 0 & 0 & 7 & 1 & 11 & 0 & 6 & 0 & 0 & 0 & 8 & 0 & 0 & 0 \\
\hline Srumbung & 7 & 0 & 7 & 0 & 11 & 0 & 6 & 1 & 6 & 0 & 0 & 0 & 4 & 0 \\
\hline Dukun & 7 & 0 & 7 & 1 & 8 & 1 & 6 & 0 & 0 & 0 & 0 & 0 & 0 & 0 \\
\hline Kemalang & 7 & 0 & 7 & 0 & 11 & 1 & 6 & 0 & 6 & -1 & 0 & 0 & 6 & 0 \\
\hline Musuk Cepogo & 7 & 0 & 7 & 0 & 11 & 0 & 6 & 0 & 0 & 0 & 0 & 0 & 0 & 0 \\
\hline Selo & 7 & 0 & 7 & 1 & 11 & 0 & 6 & 0 & 0 & 0 & 0 & 0 & 0 & 0 \\
\hline Jumlah & 42 & 0 & 49 & -4 & 74 & -2 & 42 & -1 & 18 & -1 & 16 & 0 & 16 & 0 \\
\hline
\end{tabular}

Sumber: Olahan Peneliti, 2019

"Dulu di Suroteleng resisten sekali, banyak pelanggaran. Tapi kemudian masyarakat bertanya-tanya kenapa kok harus dijaga. Akhirnya masyarakat sadar ternyata ini buat masyarakat sendiri. Kalau hutan rusak, mereka sendiri yang rugi. Mereka sadar karena mereka memanfaatkan air dari mata air di atas. Sekarang kondisi tegakan di Suroteleng justru paling bagus. Tahun 
2016 ada 17 pohon Acacia decurrens tumbang, sampai sekarang posisinya tidak berubah, masyarakat tidak berani mengambil." (Wahid - Kares Selo BTNGM, hasil wawancara tanggal 25 September 2018).

Hasil wawancara membuktikan bahwa pendekatan yang dilakukan oleh BTNGM kepada masyarakat memberikan hasil positif. Kepedulian masyarakat akan kelestarian alam Merapi dapat dilihat pula dari keterlibatan masyarakat secara sukarela dalam kelompok Masyarakat Mitra Polhut (MMP) dan Masyarakat Peduli Api (MPA). MMP dan MPA adalah mitra BTNGM dalam melakukan pengamanan dan perlindungan kawasan.

Hal-hal tersebut di atas membawa dampak positif bagi keberlangsungan ekologi pada kawasan TNGM termasuk zona inti. Hal ini dapat dilihat dari ditemukannya keanekaragaman hayati tinggi pada kawasan Gunung Bibi. Salah satunya yaitu ditemukannya sebanyak 59 jenis burung dari 174 jenis burung yang telah teridentifikasi di seluruh kawasan TNGM, diantaranya masuk dalam kategori terancam punah, yaitu Elang Jawa, Serendit Jawa, dan Takur Tulung Tumpuk. Semakin banyak fauna tinggal dan berkembang biak di kawasan tersebut maka mengindikasikan bahwa pada zona inti berhasil dipertahankan fungsi sesuai peruntukkannya.

\section{Zona Rimba}

Zona rimba memiliki luas 2.980,19 Ha. Hasil evaluasi pada zona rimba menunjukkan nilai positif pada Resort Srumbung, Kemalang, dan Musuk Cepogo. Namun masih terdapat nilai negatif pada Resort Cangkringan, Pakem Turi, Dukun, dan Selo yang disebabkan adanya aktivitas perumputan. Sesuai dengan fungsinya zona

rimba menjadi pendukung kepentingan pelestarian zona inti dan pemanfaatan. Aktivitas perumputan di zona rimba dapat mengancam keberlangsungan ekosistem pada zona rimba, inti, dan pemanfaatan apabila tidak dikendalikan. Sebagai upaya untuk mengatasi hal tersebut, pada tahun 2018 BTNGM melakukan inventarisasi perumputan dalam rangka penataan perumput pada kawasan TNGM. Kegiatan tersebut diawali dengan sosialisasi kepada perumput di kawasan TNGM. Data yang diperoleh penulis dari megikuti acara "Membangun Kemitraan Pemanfaatan Zona Tradisional TNGM" di Desa Ngargomulyo, Kecamatan Dukun, Kabupaten Magelang tersaji pada Tabel 2.

Hasil evaluasi menunjukan masih adanya aktivitas perumputan di zona rimba. Aktivitas perumputan di kawasan TNGM termasuk zona rimba disebabkan keterlanjuran yang dibiarkan oleh pengelola kawasan Merapi sebelum menjadi taman nasional, belum adanya kegiatan inventarisasi perumput sehingga terdapat kekurangan data yang dimiliki sebagai bahan penyusunan maupun review zonasi sampai dengan tahun 2016, belum adanya batas zona dalam kawasan TNGM seperti yang diamanatkan dalam Permenlhk Nomor P.76/Menlhk-Setjen/2015 sehingga menyebabkan masyarakat tidak mengetahui pasti letak masing-masing zona.

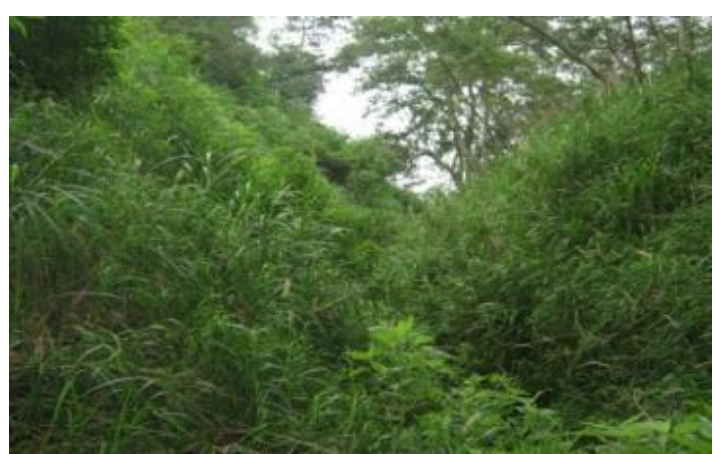

Gambar 3. Zona Rimba di Mriyan Sumber: TNGM, 2016 
Tabel 2.

Data Perumputan Desa Ngargomulyo, Kecamatan Dukun, Kabupaten Magelang

\begin{tabular}{lll}
\hline Asal Dusun & Lokasi Perumputan & Zona \\
\hline Sabrang & Kronya, Koci, Padasan/Kotes & ZP, ZTr, ZRi \\
Kembang & Semen, Kronya, Bulu, Pomahan Bendo & ZTr, ZP, ZRi, ZRi \\
Tanen & Kronya, Koci, Bendo, Bulu & ZTr, ZTr, ZRi, ZRi \\
Gemer & Deles, Tugu, Padasan & ZTr, ZTr, ZRi \\
Batu Ngisor & Bendo & ZRi \\
Braman & Padasan, Gal Braman, Kronya & ZRi, ZTr, ZTr \\
Tangkil & Deles & ZTr \\
Bojong & Deles, Braman & ZTr, ZTr \\
Ngandong & Barman, Kikis & ZTr, ZTr \\
Batur Duwur & Deles, Braman, Padasan, Bendo, Berengan & ZTr, ZTr, ZRi, ZRi, ZTr - \\
& & ZP \\
Karanganyar & Barman & ZTr \\
\hline
\end{tabular}

Sumber: Hasil Wawancara, 2018

\section{Zona Pemanfaatan}

Zona pemanfaatan pada kawasan TNGM memiliki luas 461,73 Ha. Zona pemanfaatan pada TNGM dibagi menjadi 2, yaitu wisata alam dan jasa lingkungan air. Pemanfaatan wisata alam yang telah dikembangkan di TNGM, yaitu Obyek Wisata Alam Turgo, Tritis, Tlogo Nirmolo/Goa Jepang, Tlogo Muncar, Gandok, Kalikuning, Kaliadem, Deles, Air Terjun Totogan, Goa Lowo, dan Jalur Pendakian Selo, serta Jurang Jero. Salah satu lokasi wisata di Resort Turi Pakem tersaji pada Gambar 4.

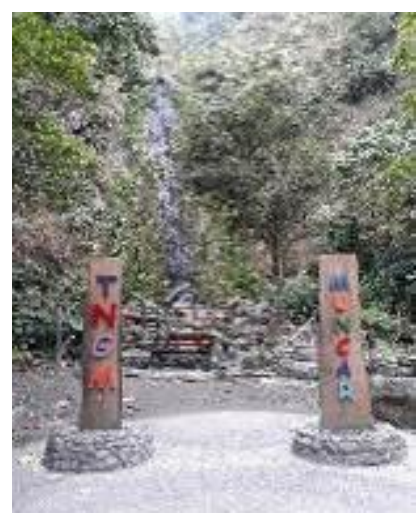

Gambar 4. Lokasi Wisata Tlogo Muncar Sumber: Dokumentasi Peneliti, 2018
Pada zona pemanfaatan jasa lingkungan air terdapat beberapa sumber air yang sebagian telah dimanfaatkan oleh masyarakat. Hasil inventarisasi BTNGM tahun 2018 ada sebanyak 35 mata air yang tersebar di berbagai zona di kawasan TNGM. Hasil evaluasi terhadap zona pemanfaatan menunjukkan efektifitas pada Resort Cangkringan, Pakem Turi, Srumbung, Musuk Cepogo, dan Selo, namun masih terdapat nilai negatif di Resort Dukun dan Kemalang karena adanya aktivitas yang tidak sesuai peruntukkannya yaitu perumputan. Peta perumputan pada Resort Dukun yang menunjukkan adanya kegiatan perumputan tersaji pada Gambar 5.

Penilaian pada zona pemanfatan secara umum menunjukkan peraturan zonasi berlaku efektif mengatur aktivitas pada zona pemanfaatan dalam pencapaian tujuan penetapannya. Masyarakat Merapi turut menjaga sumber air dan kawasan wisata yang ada di TNGM. Hal ini disebabkan mereka memanfaatkan sumber air di TNGM untuk pemenuhan kebutuhan sehari-hari dan ikut merasakan manfaat dari adanya kawasan wisata di TNGM. BTNGM menjalin kerja sama dengan berbagai pihak 
termasuk masyarakat dalam pengembangan wisata, sehingga tercipta hubungan saling menguntungkan dalam mengembangkan dan melestarikan kawasan di TNGM. Semakin terjaganya kawasan wisata di TNGM maka akan semakin berkembang pula wisata alam di TNGM, sehingga semakin menggeliatkan perekonomian masyarakat di sekitar kawasan.

\section{Zona Tradisional}

Zona tradisional merupakan areal kompromi antara pihak BTNGM dengan masyarakat desa penyangga. Zona tradisional memiliki luas 1.504,62 Ha. Keberadaan zona tradisional ditujukan untuk mengakomodir masyarakat yang selama ini melakukan aktivitas pemafaatan sumber daya alam di TNGM untuk memenuhi berbagai macam kebutuhan hidupnya, yaitu pangan, pakan ternak, dan kayu bakar. Interaksi masyarakat di dalam kawasan yang paling banyak dilakukan adalah perumputan. Kegiatan perumputan dilakukan 1-2 kali sehari, pagi sampai menjelang siang hari. Jenis rumput yang paling banyak dimanfaatkan oleh perumput adalah kolonjono. Hasil perumputan diangkut dengan berjalan kaki, menggunakan sepeda motor, gerobak, dan sling. Di dalam zona tradisional terdapat pola perumputan berupa pendudukan lahan yang disebut sanggeman/klebengan/erepan. Sanggeman/klebengan/erepan tersebut memberikan batasan wilayah perumputan antar masyarakat.

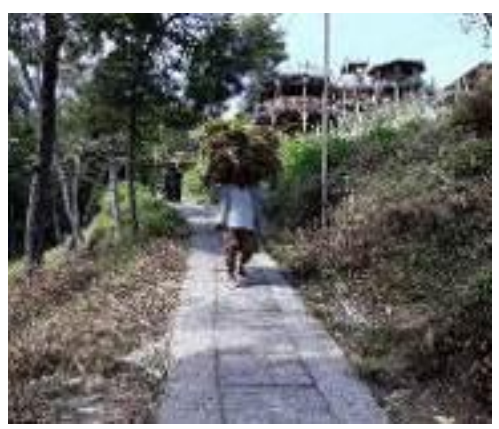

Gambar 6. Aktivitas perumput di Selo Sumber: Dokumentasi Peneliti, 2018

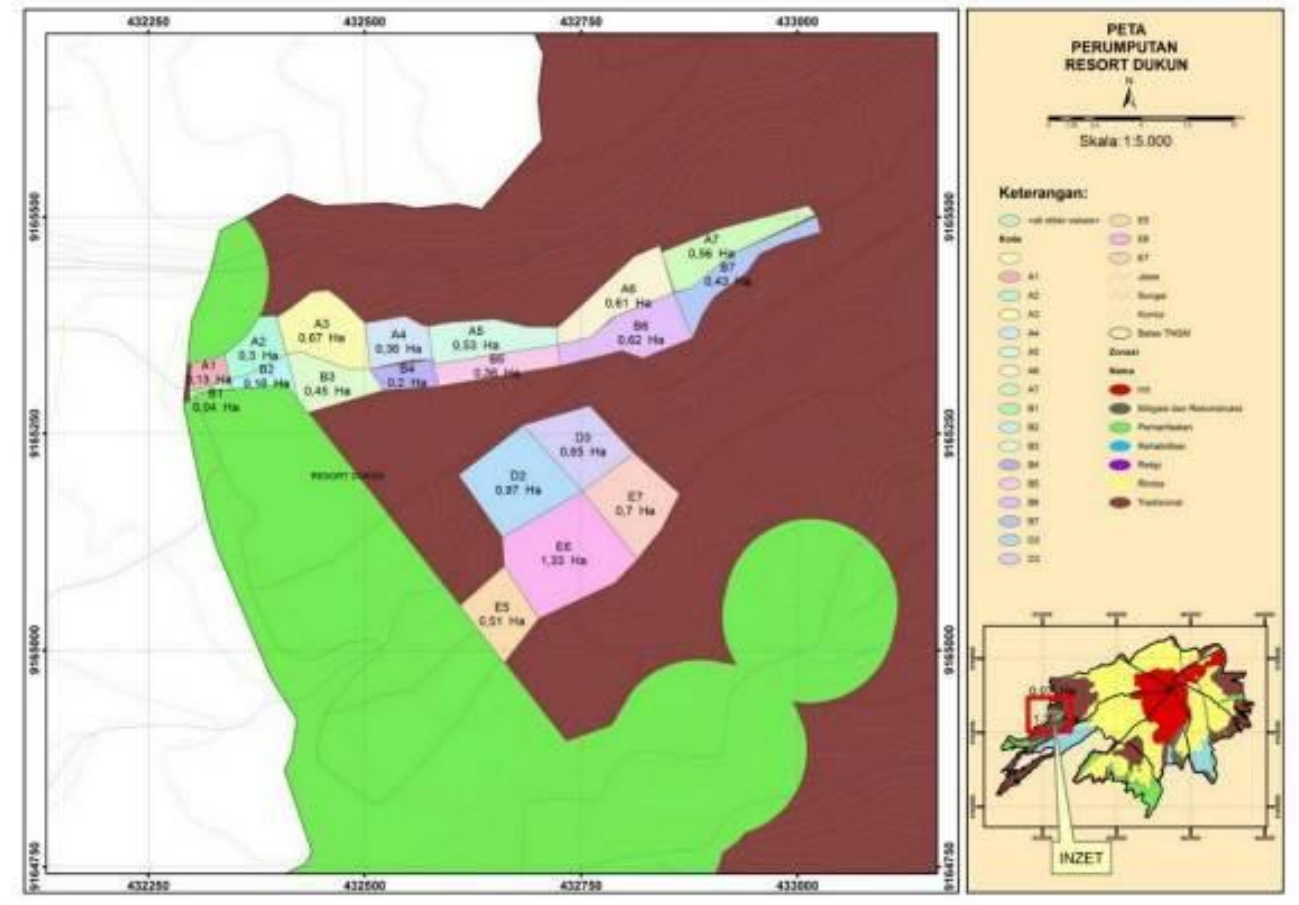

Gambar 5. Peta Perumputan di Resort Dukun Sumber: BTNGM, 2017 
Walau mengakomodir aktivitas masyarakat, tidak serta merta memberikan kebebasan memanfaatkan lahan yang ada di zona tradisonal. Hasil evaluasi terhadap zona tradisional menunjukkan efektifitas pada Resort Cangkringan, Pakem Turi, Dukun, Kemalang, Musuk Cepogo, dan Selo, serta nilai negatif pada Resort Srumbung yang disebabkan adanya aktivitas perambahan berupa penanaman jagung, kacang panjang, ubi jalar, salak pondoh, cabai, padi, dan sengon. Lokasi perambahan masyarakat ini lebih dikenal dengan sebutan tanah vonis. Tanah vonis secara administratif terletak di Desa Ngablak, Kecamatan Srumbung, Kabupaten Magelang. Sejarah tanah vonis berawal ketika masyarakat kembali menggarap lahan pertanian yang telah mereka tinggalkan akibat dampak erupsi Merapi tahun 1930 dan 1968. Warga kemudian memanfaatkan situasi dimana banyak patok lahan hilang untuk ikut menggarap tanah yang berbatasan dengan Hutan Produksi yang di kelola oleh Perhutani KPH Kedu Utara (yang selanjutnya disebut Perhutani). Awalnya terjadi pembiaran cukup lama terhadap aktivitas masyarakat tersebut oleh Perhutani. Namun pada akhirnya Perhutani membawa kasus perambahan tersebut ke meja hijau dengan hasil keputusan Pengadilan Negeri Mungkid, Magelang memenangkan Perhutani sebagai penggugat, tetapi berkewajiban memberikan hak kelola lahan kepada masyarakat. Tanah vonis memiliki luas \pm $56 \mathrm{Ha}$, dengan jumlah penggarap sebanyak 40 orang yang saat ini telah berkembang menjadi 90 orang. Perambahan yang dilakukan oleh masyarakat dikhawatirkan akan semakin meluas dan membahayakan kelestarian ekosistem Merapi. Seperti telah disampaikan sebelumnya, BTNGM saat ini sedang berusaha untuk mengatasi ketidaksesuaian yang terjadi di zona tradisional dengan melakukan penataan aktivitas perumputan yang ada di dalamnya. Tahap awal yang dilakukan yaitu inventarisasi perumputan di kawasan TNGM, selanjutnya akan ditindaklanjuti dengan penyusunan perjanjian kerja sama antara masyarakat dengan BTNGM dalam rangka mengakomodir kepentingan masyarakat tanpa mengesampingkan konservasi alam dan keanekaragaman hayati sesuai yang diamanatkan Peraturan Menteri Kehutanan Nomor P.85/MenhutII/2014 tentang Tata Cara Kerja Sama Penyelenggaraan Kawasan Suaka Alam dan Kawasan Pelestarian Alam.

Tidak dapat dipungkiri bahwa interaksi masyarakat di dalam kawasan TNGM menimbulkan pengaruh positif maupun negatif terhadap kawasan, sehingga dalam pengelolaannya BTNGM berupaya mengurangi interaksi negatif tersebut dengan melakukan kegiatan pemberdayaan di daerah penyangga. Kegiatan pemberdayaan masyarakat yang dilakukan oleh BTNGM, yaitu pelibatan masyarakat dalam pengembangan wisata berbasis komunitas/desa, pemantauan sumber daya, peningkatan perilaku ramah lingkungan, dan peningkatan ketangguhan komunitas terhadap bencana kegunungapian. Kegiatan pemberdayaan masyarakat diharapkan dapat mengurangi ketergantungan masyarakat terhadap sumber daya alam di kawasan TNGM.

\section{Zona Rehabilitasi}

Zona rehabilitasi merupakan kawasan taman nasional yang telah mengalami kerusakan sehingga perlu dilakukan pemulihan ekosistem. Pada kawasan TNGM terdapat 3 resort yang memiliki zona rehabilitasi, yaitu Resort Cangkringan, Srumbung, dan Kemalang. Zona 
rehabilitasi memiliki luas sebesar 418,42 Ha. Hasil evaluasi terhadap zona rehabilitasi menunjukkan nilai positif pada Resort Cangkringan dan Srumbung, sedangkan terdapat nilai negatif pada Resort Kemalang.

Berdasarkan inventarisasi perumput yang dilakukan oleh BTNGM tahun 2018 didapatkan hasil adanya aktivitas perumputan di dalam zona rehabilitasi pada Resort Kemalang. Namun secara keseluruhan dilihat dari perubahan tutupan lahan TNGM dari tahun 2011 dan 2015 menunjukkan hasil yang positif. Peta Tutupan Lahan TNGM Tahun 2011 dan 2015 tersaji pada Gambar 7. Berdasarkan perubahan tutupan lahan dari 2011 ke 2015 dapat dilihat bahwa lahan terbuka semakin berkurang dari 2.155,54 Ha menjadi $1.131,10$ Ha atau berubah sebanyak $47,53 \%$. Tutupan lahan berupa hutan sekunder menunjukkan perubahan sebesar 69\% atau bertambah seluas 1.295,46 Ha. Peningkatan jumlah hutan sekunder merupakan hasil positif dari kegiatan rehabilitasi lahan yang dilakukan oleh BTNGM bekerja sama dengan berbagai pihak yang peduli terhadap kelangsungan pelestarian alam di kawasan Merapi. Hal ini didukung pula dengan adanya beberapa jenis vegetasi yang masih dapat bertahan dari erupsi Merapi tahun 2010, salah satunya adalah tanaman Acacia decurrens. Perubahan paling signifikan ditunjukkan oleh tutupan lahan berupa pertanian campur semak dengan perubahan sebesar 340,26\%.
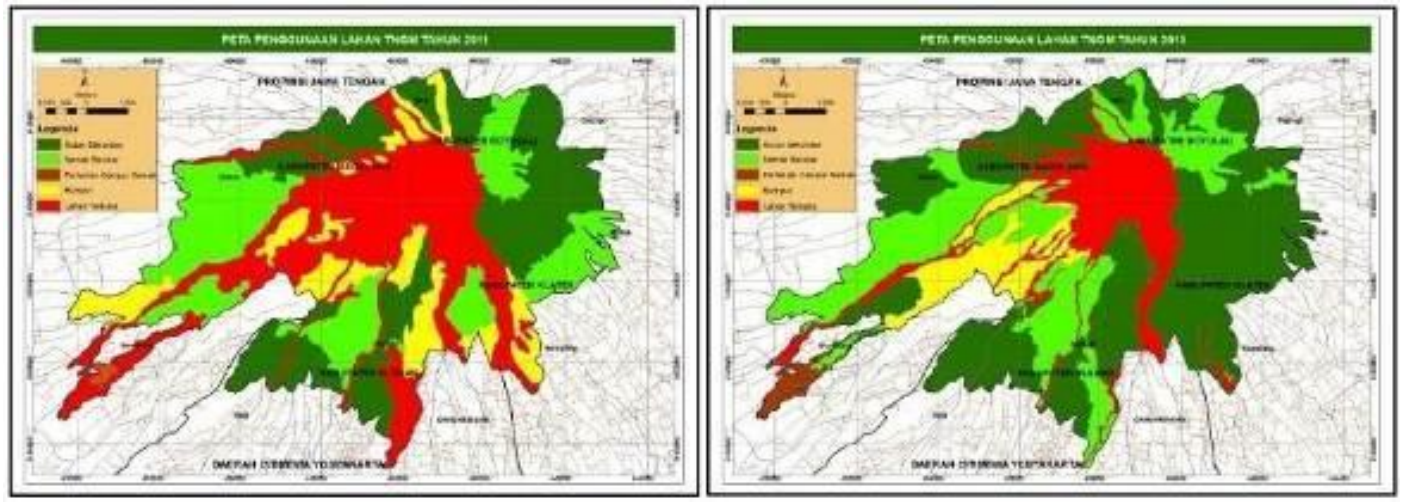

Gambar 7. Peta Tutupan Lahan TNGM Tahun 2011 dan 2015

Sumber: TNGM, 2016

Tabel 3.

Prosentase Perubahan Tutupan Lahan dari 2011 ke 2015

\begin{tabular}{llccccc}
\hline No & \multicolumn{1}{c}{ Nama PL } & PL 2011 & $\begin{array}{c}\text { Persen } \\
(\%)\end{array}$ & PL 2015 & $\begin{array}{c}\text { Persen } \\
(\%)\end{array}$ & $\begin{array}{c}\text { Perubahan } \\
(\%)\end{array}$ \\
\hline 1 & Lahan terbuka & $2.155,54$ & 32,62 & $1.131,10$ & 17,12 & $-47,53$ \\
2 & Rumput & 874,25 & 13,23 & 491,01 & 7,43 & $-43,84$ \\
3 & Semak belukar & $1.677,44$ & 25,39 & $1.712,43$ & 25,92 & 2,09 \\
4 & Pertanian campur semak & 22,70 & 0,34 & 99,93 & 1,51 & 340,26 \\
5 & Hutan sekunder & $1.877,59$ & 28,42 & $3.173,05$ & 48,02 & 69,00 \\
\hline
\end{tabular}

Sumber: BTNGM, 2016 
Namun secara keseluruhan jumlah pertanian campur semak hanya seluas 99,93 $\mathrm{Ha}$ atau sebesar $1,51 \%$ dari luas total TNGM. Prosentase perubahan tutupan lahan tahun 2011 dan dan 2015 tersaji pada Tabel 3. Perubahan tutupan lahan tersebut berdampak pula pada keberlangsungan ekosistem yang semakin membaik. Rapid assessment yang dilakukan BTNGM pasca erupsi 2010 menunjukkan sebaran Elang Jawa terpantau di Dukun, Turi, dan Kemalang, serta Lutung Jawa terpantau di wilayah Pakem dan Musuk. Dalam kurun waktu 4 tahun atau sampai dengan 2015 sebaran Elang Jawa terpantau bertambah di Dukun, Turi, Pakem, Kemalang, Musuk, dan Cepogo, serta Lutung terpantau di Pakem, Musuk, Dukun, Kemalang, dan Gunung Bibi.

\section{Zona Religi, Budaya, dan Sejarah}

Zona religi, budaya, dan sejarah ditujukan untuk mengakomodir kepentingan religi, adat budaya, perlindungan nilai-nilai budaya atau sejarah, serta kegiatan wisata terbatas yang berkaitan dengan agenda kegiatan budaya. Zona ini terletak di Resort Cangkringan dengan luas 11,57 Ha. Zona religi, budaya, dan sejarah terbagi menjadi dua lokasi, yaitu lokasi labuhan dan jalur yang dilewati untuk prosesi labuhan, serta lokasi dan trek ke petilasan Syekh Jumadil Kubro. Hasil evaluasi menunjukkan nilai positif pada zona ini dan tidak terdapat aktivitas pelanggaran di dalamnya. Hal ini disebabkan oleh kepercayaan masyarakat Merapi dengan segala kearifan lokalnya masih sangat mensakralkan keberadaan Merapi yang dihubungkan dengan Laut Selatan, dan Keraton Yogyakarta. Masyarakat Merapi mempercayai akan terhindar dari dampak bencana erupsi Merapi apabila mereka memberikan penghormatan berupa sesajen pada waktu tertentu kepada "penunggu Merapi". Kearifan lokal yang berlangsung turun temurun ini secara tidak langsung sangat mendukung kelestarian kawasan Merapi.

7. Zona Khusus Mitigasi dan Rekonstruksi

Zona khusus mitigasi dan rekonstruksi memiliki luas 189,88 Ha. Zona ini merupakan ciri khas dari TNGM. Hal ini disebabkan rutinitas Merapi yang secara periodik mengeluarkan material erupsi. Zona ini terbagi menjadi dua, yaitu zona khusus mitigasi dan rekonstruksi jalur material vulkanik, serta zona khusus mitigasi dan rekonstruksi peralatan pemantauan aktivitas Merapi. Pada zona mitigasi dan rekonstruksi peralatan pemantau aktivitas Merapi terdapat peralatan yang dipasang oleh Balai Penyelidikan dan Pengembangan Teknologi Kebencanaan Geologi (BBPTKG) berupa tower power, dan bunker untuk cctv di Pasar Bubrah (Selo), Deles (Kemalang), dan jalur labuhan (Cangkringan). Penentuan status waspada Merapi bukan kewenangan BTNGM, melainkan oleh BBPTKG yang salah satu fungsinya adalah memberikan rekomendasi penetapan tingkat aktivitas dan rekomendasi teknis mitigasi Merapi. Pengelolaan zona khusus mitigasi dan rekonstruksi jalur material vulkanik lebih kompleks, meliputi kawasan aliran Kali Putih, Kali Gendol, dan Kali Woro. Terdapat berbagai macam konflik kepentingan di dalamnya terutama di Kali Putih. Hal ini dikarenakan kesalahan dalam memahami peraturan yang berlaku, kepentingan politik, hingga kebutuhan ekonomi. Sebagian pihak memandang bahwa mitigasi dapat dilakukan pada aliran sungai yang dipahami dari hulu sampai hilir, tanpa memandang adanya fungsi konservasi didalamnya. 


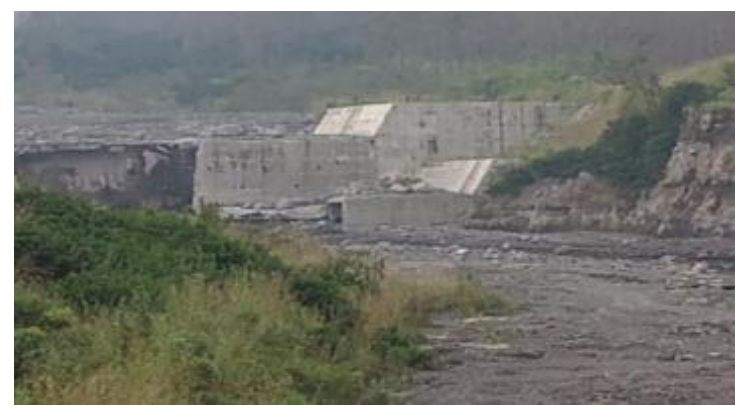

Gambar 8. Zona Khusus Mitigasi dan

Rekonstruksi Jalur Material Vulkanik.

Hal tersebut bertentangan dengan pemahaman BTNGM yang memahami sungai dari fungsi konservasi. Namun dalam perkembangannya, perjuangan yang dilakukan BTNGM demi konservasi alam membuahkan hasil. Saat ini BTNGM telah berhasil menghentikan penambangan menggunakan alat berat yang berada dalam kawasan TNGM.

\section{SIMPULAN}

Berdasarkan analisis data dan pembahasan mengenai evaluasi efektivitas zonasi pada TNGM, dapat ditarik kesimpulan bahwa pada masing-masing zona di TNGM secara umum menunjukkan peraturan zonasi berlaku efektif mengatur setiap aktivitas pada masing-masing zona dalam pencapaian tujuan penetapannya. Hal ini disebabkan BTNGM dalam pengelolaan kawasan TNGM semakin intensif melibatkan masyarakat di dalam pengambilan keputusan dan aktivitas yang dilakukan di kawasan TNGM, serta terjalinnya komunikasi dan koordinasi yang semakin baik antara pihak pemangku kawasan dengan masyarakat maupun stakeholder lain yang berkepentingan di dalam kawasan TNGM. Kedekatan yang terjalin antara petugas lapangan dan masyarakat di sekitar Merapi mampu membuka hati masyarakat serta menumbuhkan kesadaran akan arti penting konservasi dan mitigasi bagi kelangsungan kehidupan mereka di masa kini dan masa yang akan datang. Namun demikian, BTNGM masih mempunyai "pekerjaan rumah" untuk mengatasi masalah perumputan dan perambahan liar di dalam kawasan TNGM. Perlu dilakukan sosialisasi kepada stakeholder (termasuk masyarakat) mengenai ketujuh zona tentang fungsi dan perannya yang ada di TNGM, pemberian batas pada masing zona di lapangan, penataan aktivitas masyarakat di dalam kawasan, serta penegakkan aturan tentang pelarangan kegiatan-kegiatan yang tidak memenuhi persyaratan demi keselamatan dan keberlangsungan kehidupan keanekaragaman hayati di dalamnya, serta keberlangsungan hidup manusia di sekitarnya.

\section{DAFTAR PUSTAKA}

Badan Perencanaan Pembangunan Nasional. (2009). Pedoman Evaluasi Kinerja Pembangunan Sektoral. Jakarta: Badan Perencanaan Pembangunan Nasional.

Balai Taman Nasional Gunung Merapi. (2015). Rencana Pengelolaan Taman Nasional Gunung Merapi 2015-2024. Yogyakarta, DI: Balai Taman Nasional Gunung Merapi.

Balai Taman Nasional Gunung Merapi. (2016). Zonasi Taman Nasional Gunung Merapi Tahun 2015. Yogyakarta, DI: Balai Taman Nasional Gunung Merapi. 
Dunn, W.N. (1994). Public Policy Analysis: An Introduction Second Edition. In Wibawa,S., Astidani, D., Hadna, A.H., Purwanto, E.A., Darwin, M. (Ed). Pengantar Analisis Kebijakan Publik (pp 610). Yogyakarta, DI: Gadjah Mada University Press.

Kementerian Kehutanan RI. (2004). Surat Keputusan Menteri Kehutanan tentang Perubahan Fungsi Kawasan Hutan Lindung, Cagar Alam dan Taman Wisata Alam pada kelompok hutan Gunung Merapi seluas \pm 6.410 Ha yang terletak di Kabupaten Magelang, Boyolali dan Klaten Provinsi Jawa Tengah dan Kabupaten Sleman Provinsi Daerah Istimewa Yogyakarta (SK.134/Menhut-II/2004). Jakarta: Kementerian Kehutanan.

Kementerian Kehutanan RI. (2006). Peraturan Menteri Kehutanan tentang Pedoman Zonasi Taman Nasional (Permenhut Nomor P.56/Menhut-II/2006). Jakarta: Kementerian Kehutanan.

Kuswijayanti, E.R., Dharmawan, A.H., Kartodihardjo, H. (2007). Krisis-krisis sociopolitico-ecology kawasan konservasi. Jurnal Transdisiplin Sosiologi, Sosiologi dan Ekologi Manusia, 1, 41-66.

Kementerian Kehutanan RI. (2014). Peraturan Menteri Kehutanan tentang Tata Cara Kerja Sama Penyelenggaraan Kawasan Suaka Alam, dan Kawasan Pelestariaan Alam (Permenhut Nomor P.85/Menhut-II/2014). Jakarta: Kementerian Kehutanan.

Kementerian Lingkungan Hidup dan Kehutanan RI. (2015). Peraturan Menteri Lingkungan Hidup dan Kehutanan tentang Kriteria Zona Pengelolaan Taman Nasional dan Blok Pengelolaan Cagar Alam, Suaka Margasatwa, Taman Hutan Raya, dan Taman Wisata Alam (PermenLHK Nomor P.76/Menlhk-Setjen/2015). Jakarta: Kementerian Lingkungan Hidup dan Kehutanan.

Nugroho, R. (2009). Public Policy. Jakarta: Elex Media Komputindo.

Nugroho, R. (2012). Metode Penelitian Kebijakan. Yogyakarta, DI: Pustaka Pelajar.

Pemerintah Indonesia. (1990). Undang-undang Nomor 5 Tahun 1990 tentang Konservasi Sumberdaya Alam Hayati dan Ekositem. Jakarta: Sekretariat Negara.

Subarsono. (2005). Analisis Kebijakan Publik. (1 ${ }^{\text {th }}$ ed.). Yogyakarta, DI: Pustaka Pelajar. 